Falter, M. L., Robinson, M. G., Kim, O. S., and Go, S.Ch. (1972). Infection and splenic function in sickle cell anemia. Pediatric Research, 6, 365

Gotoff, S. P. (1974). Neonatal immunity. Fournal of Pediatrics, $85,149$.

Holroyde, C. P., Oski, F. A., and Gardner, F. H. (1969). The 'pocked erythrocyte' red-cell surface alterations in reticuloendothelial immaturity of the neonate. New England fournal of Medicine, 281, 516.

Ingram, G. I. C. (1961). Increase in antihaemophilic globulin activity following infusion of adrenaline. Fournal of Physiology, 156, 217.

Rizza, C. R., and Eipe, J. (1971). Exercise, factor VIII and the spleen. British fournal of Haematology, 20, 629.

Rodman, N. F., Jr., Barrow, E. M., and Graham, J. B. (1958). Diagnosis and control of the hemophilioid states with the partial thromboplastin time (PTT) test. American fournal of Clinical Pathology, 29, 525.

Webster, W. P., Reddick, R. L., Roberts, H. R., and Penick, G. D. (1967). Release of factor VIII (antihaemophilic factor) from perfused organs and tissues. Nature, 213, 1146.

Z. SPIRER, ${ }^{\star}$ I. Shalit, V. Zakuth, S. SVirskyFein, B. Milbauer, and N. Bogair

Paediatric Department ' $A$ ', Neonatal Unit and Immunology Department, Rokach-Hadassah Hospital, Sackler School of Medicine, Tel-Aviv, Israel.

${ }^{\star}$ Correspondence to Dr. Z. Spirer, P.O. Box 51, Tel-Aviv, Israel.

\section{Jaundice and bilirubin levels in Greek children with favism}

Favism is common in certain Mediterranean countries, especially Greece, Italy, Israel (among Sephardic Jews), and China. It affects individuals deficient in red cell glucose 6-phosphate dehydrogenase (G-6-PD) and mainly those with the Mediterranean variant. The main clinical features are severe anaemia, haemoglobinuria, and jaundice (Harris, 1963; Dacie, 1967) of these, only anaemia; has been studied (Kattamis, Kyriazakou, and Chaidas, 1969). The severity of jaundice and the bilirubin levels during the acute favic crisis have not been studied, though bilirubin levels were occasionally measured in individual cases by Sansone, Piga, and Segni (1958). During the past decade we have noticed in a large series of patients with favism that jaundice was not present in all cases and that when present its severity varied considerably. We therfore noted the incidence of jaundice in a series of 85 patients with favism and measured its severity by estimating bilirubin levels during the acute haemolytic crisis.

\section{Patients}

Eighty-five patients with favism aged from 1.5 to 12 years admitted to the 1st Department of Paediatrics of the University of Athens from 1969 to 1972 were studied. Favism was diagnosed when an acute haemolytic syndrome occurred after the ingestion of fresh or dry fava beans. The clinical signs consisted of gross haemoglobinuria and anaemia, while the laboratory findings were of fragmented red cells, spherocytosis, low haemoglobin, and reticulocytosis associated with red cell G-6-PD deficiency.

On admission the patients were carefully examined for clinical jaundice, and laboratory investigations before transfusion included $\mathrm{Hb}$, packed cell volume, red cell and reticulocyte counts, and bilirubin determination; G-6-PD activity was measured by the Brilliant Cresyl Blue (BCB) decolorization test. In girls in addition to the BCB test enzymic activity was determined quantitatively and histochemically by the cyanmethaemoglobin elution technique. The results were measured according to standards used in our laboratory (Kattamis, 1967).

\section{Results}

The total bilirubin levels in 85 children during the acute favic crisis and before transfusion are shown in Fig. 1. The severity of jaundice was related to the bilirubin level.

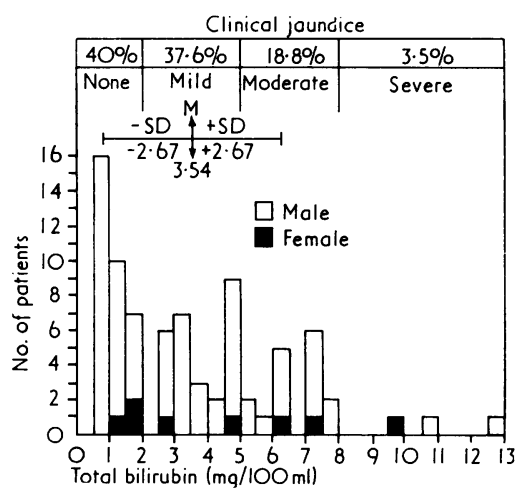

FIG. 1.-Distribution of bilirubin levels and severity of jaundice in 85 Greek children with favism.

The bilirubin levels varied widely, ranging from $0.5 \mathrm{mg} / 100 \mathrm{ml}$ to $13 \mathrm{mg} / 100 \mathrm{ml}$ with a mean $( \pm S D)$ of $3 \cdot 54 \pm 2.67 \mathrm{mg} / 100 \mathrm{ml}$. Low bilirubin levels $(2 \mathrm{mg} / 100 \mathrm{ml})$ were found in $34(40 \%)$ of the patients. At these levels jaundice was usually clinically undetectable. Notably $17(20 \%)$ had normal bilirubin levels $(<1 \mathrm{mg} / 100 \mathrm{ml})$ despite acute haemolysis and anaemia. In the remainder the variations in bilirubin levels and jaundice were as follows: $31(38 \%)$ had mild jaundice with bilirubin levels ranging of $2 \cdot 0-4.9 \mathrm{mg} / 100 \mathrm{ml} ; 16$ $(19 \%)$ had moderate jaundice with bilirubin levels of $5 \cdot 0-7 \cdot 9 \mathrm{mg} / 100 \mathrm{ml}$; and only $3(4 \%)$ had severe jaundice with bilirubin exceeding $8 \mathrm{mg} / 100 \mathrm{ml}$. As a rule bilirubin was unconjugated though a small 
proportion of conjugated bilirubin was present in some patients.

We looked to see whether bilirubin levels were related to those of haemoglobin. If bilirubinaemia was the result of severe haemolysis a negative correlation between bilirubin and $\mathrm{Hb}$ levels and a positive one between bilirubin and reticulocytes would be expected. As seen from the correlation coefficient (Fig. 2) no such correlation was found.

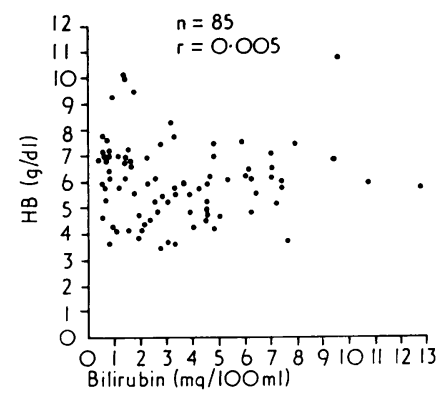

FIG. 2.-Correlation of haemoglobin to bilirubin levels in 85 patients with acute favic crisis.

Evidently patients with low $\mathrm{Hb}$ and severe anaemia had both high and low bilirubin levels, while others with rather high $\mathrm{Hb}$ had varying levels of bilirubin. Nor was there any correlation between bilirubin and reticulocyte levels $(r=0 \cdot 10)$.

Furthermore, bilirubin levels were not related to the age of the patients or the day of illness-that is, the number of days since the ingestion of fava beans. Serum transaminases (glutamic oxaloacetic and glutamic pyruvic) were slightly raised; this was attributed to intravascular haemolysis and not to liver involvement.

\section{Discussion}

The extreme variations in bilirubin levels during the acute favic crisis cannot be easily explained. In the high proportion of patients with clinically undetectable or mild jaundice and low bilirubin levels $(<5 \mathrm{mg} / 100 \mathrm{ml})$ the increased rate of bilirubin production after haemolysis could be compensated by the ability of the liver to conjugate the large quantities of bilirubin produced. Furthermore, much of the haemoglobin released by intravascular haemolysis is excreted in the urine and thus the amount of bilirubin produced is lower than what might be expected from the amount of haemoglobin released from the destroyed red cells. In contrast to newborns, the liver in older infants and children is capable of conjugating considerable amounts of bilirubin (more than tenfold the daily production of normal individuals). Assuming that much of the haemoglobin released during intravascular haemolysis in favism is excreted in the urine and the amount of bilirubin produced is not high, the rather low bilirubin levels found in most but not all patients could be explained on the basis of a well-functioning liver.

Fessas, Doxiadis, and Valaes (1962) suggested that the severe neonatal jaundice in Greek newborns with G-6-PD deficiency might be due to an additional genetic factor, probably hepatic, while Meloni et al. (1973) observed that the hyperbilirubinaemia in G-6-PD-deficient newborns may be largely nonhaemolytic, pointing to possible liver involvement.

Unfortunately we do not know about the severity of neonatal jaundice in all our patients. Severe neonatal jaundice was reported in 4 , and all had bilirubin levels above $6 \mathrm{mg} / 100 \mathrm{ml}$ during acute favic crisis. One of them had the highest bilirubin level $(13 \mathrm{mg} / 100 \mathrm{ml})$ of the series, and during the neonatal period he had had severe jaundice for which he received two exchange transfusions.

These data favour the hypothesis that the moderate and severe jaundice seen in a few cases of favism could be a result of the same genetic liver factor incriminated in the severe hyperbilirubinaemia observed in neonates and in cases of infective hepatitis in Greek individuals with G-6-PD deficiency (Kattamis and Tjortzatou, 1970).

\section{Summary}

Jaundice and bilirubin levels varied widely in 85 children with favism. Low bilirubin levels $(<2 \mathrm{mg} / 100 \mathrm{ml})$ with clinically undetectable jaundice were seen in $34(40 \%)$, mild jaundice in $32(38 \%)$, moderate in $16(19 \%)$, and severe $(>8 \mathrm{mg} / 100 \mathrm{ml})$ in $3(4 \%)$. Bilirubin levels were unrelated to the severity of anaemia or to reticulocytosis. The absence of bilirubinaemia and jaundice in a high proportion of the patients was attributed to the ability of the liver to conjugate large amounts of bilirubin. The extreme bilirubinaemia and jaundice observed in a minority of cases was attributed to the existence of an additional hereditary factor affecting the liver.

This work was supported by the National Hellenic Research Foundation (grant 162) and the Empirikion Foundation, Athens.

\section{REFERENCES}

Dacie, V. J. (1967). The haemolytic anaemias. Part 4. DrugInduced Haemolytic Anaemia, 2nd ed. Churchill, London.

Fessas, Ph., Doxiadis, S. A., and Valaes, T. (1962). Neonatal jaundice in glucose-6-phosphate dehydrogenase-deficient infants. British Medical fournal, 2, 1359. 
Harris, W. J. (1963). The Red Cell. Havard University Press, Cambridge, Mass.

Kattamis, C. (1967). Glucose-6-phosphate dehydrogenase deficiency in female heterozygotes and the $x$-inactivation hypothesis. Acta Paediatrica Scandinavica, Suppl. 172, 103.

Kattamis, C., and Tjortzatou, F. (1970). The hemolytic process of viral hepatitis in children with normal or deficient glucose-6phosphate dehydrogenase, activity. Fournal of Pediatrics, 77, 422.

Kattamis, C., Kyriazakou, M., and Chaidas, S. (1969). Favism. Clinical and biochemical data. Fournal of Medical Genetics, 6, 34 .
Meloni, T., Cagnazzo, G., Dore, A., and Cutillo, S. (1973). Phenobarbital for prevention of nyperbilirubinemia in glucose-6phosphate dehydrogenase-deficient newborn infants. fournal of Pediatrics, 82, 1048.

Sansome, G., Piga, A. M., and Segni, G. (1958). Il Favismo. Minerva Medica, Torino.

Christos Kattamis, Katerina Karambula, VasiLIKI IOANNIDOU, and VASILIKI HATZIKOU

Athens University, 1st Department of Paediatrics, St. Sophie's Children's Hospital, Athens 608, Greece.

The following abstract should have appeared in the Archives, October 1975, p. 825, in the Proceedings of the British Paediatric Association in place of the title 'Fffect of gestational age and intrauterine nutrition ...' by Scott et al., which was published in error.

Nutritional value of whey protein and curd protein in the low birthweight baby. $H$. $M$. Berger, P. H. Scott, Caroline Kenward, P. Scott, and B. A. Wharton. Birmingham.

Dogs and rats thrive better on a milk-containing whey as well as curd protein probably due to its higher cystine content, but the situation in humans is unclear. It is relevant to re-examine this problem since demineralized whey formulae with curd/whey ratios similar to those in breast milk, are now available (e.g. S26, Premium). We have therefore studied the nutritional progress of 29 low birthweight babies (mean gestation 36 weeks, birthweight $2 \mathrm{~kg}$ ) receiving SMA (mainly curd protein) and 28 of similar size and gestation receiving modified S26 (curd and whey protein, sodium and potassium content similar to SMA).

Babies on the curd and whey formula at 21 days were bigger (weight $2 \cdot 4 \pm 0 \cdot 13$, cf $2 \cdot 3 \pm 0.2 \mathrm{~kg}, \mathrm{P}<0.01$; length $48 \pm 1$, cf $47 \pm 1 \mathrm{~cm}, P<0.05$ ). The differences were more marked in the preterm babies. The curd and whey group had a lower plasma ribonuclease activity on day $7(1.02 \pm 0 \cdot 2$, cf $1 \cdot 38 \pm 0.4$ units
$P<0 \cdot 01$ ), and excreted less nitrogen $(N)$ due to the urea fraction, and relatively more inorganic sulphate (S) (day 10 urinary urea $52 \pm 9$, cf $75 \pm 22, P<0.05$; $\mathrm{S} / \mathrm{N}$ ratio $0 \cdot 17 \pm 0.03$, cf $0 \cdot 10 \pm 0 \cdot 04, \mathrm{P}<0 \cdot 01$ ).

Nitrogen balance studies performed towards the end of the study period gave similar results, and no differences were found in hair growth, midarm muscle circumference, fat deposition and plasma levels of sulphur amino acids, albumin, immunoglobulins, urea, and triglyceride. However, the curd and whey group did have lower plasma transferrin (day 19, 163 \pm 32 , cf $205 \pm 37, \mathrm{P}<0 \cdot 01$ ) and $\beta$ lipoprotein (day 10, 41 \pm 17 , cf $50 \pm 13, P<0 \cdot 05)$.

Overall, these results suggest that a curd and whey formula has advantages in the protein nutrition of low birthweight babies, especially the preterm ones, and does not provoke any more immunological reaction than a curd one alone. These advantages were marginal, however, so that the major argument for use of such formulae is their reduced mineral content, particularly the lower phosphate and lower renal solute load. 